\title{
LINGKUNGAN KERJA BERPENGARUH TERHADAP KINERJA \\ PEGAWAI DI DINAS PERPUSTAKAAN DAN ARSIP \\ KABUPATEN TANGERANG
}

\author{
Galuh Lutfi Fadil ${ }^{1}$ \\ Yusmedi Yusuf, SH.,Msi. ${ }^{2}$ \\ Seno Santoso, SH.,MM.,M.Kn. ${ }^{3}$ \\ Jurusan Ilmu Administrasi Negara, Fakultas Ilmu Sosial dan Ilmu Politik \\ Universitas Islam Syekh Yusuf Tangerang - Banten \\ E-mail : galuhlf227@gmail.com
}

\begin{abstract}
This research aims to describe and analyze The Influence of the Work Environment on Employee Performance in The Library and Archives Service in Tangerang District. The population in this study amounted to 48 respondents, the sampling technique used was the saturation sampling technique (census). Respondents in this study were the Library and Archives Service in Tangerang District.

The research method used is a quantitative-associative method. Then the data were analyzed using the SPSS (Statistical Product and Service Solution) for windows version 21.0 using the correlation technique with the Pearson product moment method and then proceed with regression and hypothesis testing. The results in this study are "There is a Positive and Significant Effect Between the Work Environment on the Performance of Employees in the Tangerang District Library and Archives Office". Based on obtaining the calculated t value of 7.141 while the value in t table is 2.013. Thus, according to the calculation of the statistical hypothesis if the value (7,141)> (2,013), then Ho is rejected and Ha is accepted.
\end{abstract}

Keywords : Work Environment, Employee Performance, Library and Archives.

\section{ABSTRAK}

Penelitian ini bertujuan untuk mendeskripsikan dan menganalisis pengaruh lingkungan kerja terhadap kinerja pegawai di Dinas Perpustakaan Dan Arsip Kabupaten Tangerang. Populasi pada penelitian ini berjumlah 48 responden, teknik sampling yang digunakan adalah teknik sampling jenuh (sensus). Responden pada penelitian ini adalah pegawai Dinas Perpustakaan Dan Arsip Kabupaten Tangerang.

Metode penelitian yang digunakan adalah metode kuantitatif-asosiatif. Kemudian data dianalisis menggunakan program SPSS (Statistical Product and Service Solution) for windows versi 21.0 menggunakan teknik korelasi dengan metode pearson product moment dan kemudian dilanjutkan dengan pengujian regresi dan hipotesis. Hasil dalam penelitian ini adalah "Terdapat Pengaruh Positif Dan Signifikan Antara Lingkungan Kerja Terhadap Kinerja Pegawai Di Dinas Perpustakaan Dan Arsip Kabupaten Tangerang”. Berdasarkan diperolehnya nilai t hitung sebesar 7,141 sedangkan nilai dalam t tabel yaitu sebesar 2,013. Dengan demikian, sesuai dalam hitungan hipotesis statistik jika nilai $(7,141)>(2,013)$, Maka Ho ditolak dan Ha diterima.

Kata Kunci : Lingkungan Kerja, Kinerja Pegawai, Perpustakaan dan Arsip. 


\section{PENDAHULUAN}

\section{Latar Belakang}

Setiap organisasi, baik yang berskala besar maupun kecil pada hakekatnya akan selalu berorientasi pada pencapaian suatu tujuan. Sebuah organisasi dalam menjalankan kegiatan untuk dapat mewujudkan tujuannya memiliki faktor-faktor yang saling berkaitan dan berpengaruh, salah satunya adalah sumber daya manusia.

Organisasi harus mempunyai pegawaipegawai yang mempunyai kinerja yang baik. Dengan kata lain kelangsungan suatu organisasi ditentukan oleh kinerja pegawainya, untuk itu semua aktivitas sumber daya manusia harus mendukung peningkatan kinerja sebuah organisasi. Menurut Siagian (2002) dalam Zuriani, dkk (2014:4) bahwa "Kinerja pegawai dipengaruhi oleh beberapa faktor yaitu; gaji, lingkungan kerja, budaya organisasi, kepemimpinan, motivasi kerja, disiplin kerja, kepuasan kerja, komunikasi dan faktor-faktor yang mempengaruhi kinerja pegawai lainnya".

Dari beberapa faktor di atas, salah satu faktor yang dapat meningkatkan kinerja pegawai adalah lingkungan kerja. Dalam sebuah instansi swasta maupun pemerintahan, lingkungan kerja sangat penting untuk mendapat perhatian. Meskipun lingkungan kerja tidak melaksanakan proses kerja, akan tetapi lingkungan kerja mempunyai pengaruh langsung terhadap para pegawai dalam melaksanakan kegiatannya.

Dinas Perpustakaan dan Arsip Daerah Kabupaten Tangerang merupakan instansi dalam perananya sebagai pelaksana urusan wajib perpustakaan dan kearsipan lembaga harus siap menampung, menyimpan, memelihara serta mengamankan arsip-arsip statis yang memiliki nilai sejarah di lingkungan Kabupaten Tangerang, serta sebagai lembaga yang harus melakukan pembinaan, pendampingan, penataan arsip dan pengelolaan, penyajian, perumusan pelayanan, penyimpanan bahan pustaka, kerya rekam, kerya cetak maupun kerjasama instansi ataupun pihak lain dalam bidanng perpustakaan di Kabupaten Tangerang. Oleh karena itu, lingkungan kerja menjadi salah satu yang perlu dan penting di perhatikan terkait faktor pendukung pegawai dalam menjalankan pekerjaannya dengan baik dan optimal.

Organisasi harus mampu menyediakan suasana lingkungan kerja yang nyaman, aman, dan kondusif, dengan demikian maka akan mampu mempengaruhi pegawai agar dapat bekerja dengan baik dan produktif serta mempunyai keharmonisan kerja antar sesama pegawai maupun pegawai dengan atasannya, hal itu guna untuk meningkatkan kinerja pegawai dalam pencapaian tujuan atau target dari organisasi. Sebaliknya, penyediaan lingkungan kerja yang tidak baik maka akan dapat menurunkan tingkat kinerja pegawai sehingga akan mempengaruhi dan menghambat dari pada pencapaian tujuan organisasi tersebut.

Berdasarkan pengamatan sementara yang dilakukan oleh peneliti pada Dinas Perpustakaan dan Arsip Kabupaten Tangerang masih ditemukan beberapa permasalahan khususnya terkait dengan lingkungan kerja dan kinerja pegawai diantaranya adalah :

1. Penataan dan pemanfaatan tata ruang yang belum baik, seperti dalam satu ruangan digunakan lebih dari satu atau dua orang sehingga mengakibatkan ruangan yang kurang kondusif dan arus kerja menjadi terganggu.

2. Kurangnya rasa nyaman dalam bekerja karena masih sering terdapat aroma (bau-bauan) yang kurang sedap dalam ruangan seperti dalam ruang depo arsip dan record centre.

3. Masih kurangnya kerjasama pegawai dalam bekerja dikarenakan kantor yang terpisah sehingga adanya hubungan yang kurang harmonis antar sesama pegawai.

4. Kurangnya dekorasi dan sarana prasarana yang belum lengkap, seperti pemakaian alat kantor yang masih 
dipakai bersama-sama sehingga mengakibatkan lambannya pencapaian tujuan pekerjaan.

Berdasarkan paparan di atas, tentu masalah-masalah yang ada harus dengan segera diperbaiki agar tidak menghambat pegawai dalam mencapai visi dan misi Dinas Perpustakaan dan Arsip Kabupaten Tangerang.

\section{Rumusan Masalah}

Berdasarkan latar belakang penelitian di atas peneliti merumuskan rumusan masalah sebagai berikut: "Bagaimanakah Pengaruh Lingkungan Kerja terhadap Kinerja Pegawai di Dinas Perpustakaan dan Arsip Kabupaten Tangerang?".

\section{TINJAUAN PUSTAKA}

\section{Lingkungan Kerja}

\section{Pengertian Lingkungan Kerja}

Menurut Nitisemito (1982:183) bahwa "Lingkungan kerja adalah segala sesuatu yang ada di sekitar para pekerja yang dapat mempengaruhi dirinya dalam menjalankan tugas-tugas yang di bebankan". Kemudian, Sedarmayanti (2011:2) menjelaskan bahwa "Lingkungan kerja adalah keseluruhan alat perkakas dan bahan yang dihadapi, lingkungan sekitarnya di mana seseorang bekerja, metode kerjanya, serta pengaturan kerjanya baik sebagai perorangan maupun sebagai kelompok".

Menurut Weol (2015:600) bahwa "Lingkungan kerja adalah segala sesuatu yang ada disekitar manusia, yang dapat memberikan pengaruh dalam beraktivitas dan bertindak, baik secara langsung maupun tidak langsung dalam melaksanakan kegiatan sehari-hari serta mempunyai pengaruh yang cukup besar terhadap jalannya suatu sistem kerja yang baik di dalam lingkungan kerja suatu perusahaan".

\section{Indikator Lingkungan Kerja}

Menurut Sedarmayanti (2011:28) mengungkapkan banyak faktor yang dapat mempengaruhi terbentuknya suatu kondisi lingkungan kerja, diantaranya adalah;

a. Penerangan/Cahaya di Tempat Kerja

b. Temperatur di Tempat Kerja

c. Kelembaban di Tempat Kerja

d. Sirkulasi Udara di Tempat Kerja

e. Kebisingan di Tempat Kerja

f. Getaran Mekanis di Tempat Kerja

g. Bau-bauan di Tempat Kerja

h. Tata Warna di Tempat Kerja

i. Dekorasi di Tempat Kerja

j. Musik di Tempat Kerja

k. Keamanan di Tempat Kerja

\section{Kinerja Pegawai}

\section{Pengertian Kinerja Pegawai}

Pengertian kinerja berasal dari kata job performance yang memiliki arti prestasi kerja atau prestasi kinerja. Menurut Indra Bastian yang dikutip oleh Fahmi (2015:2) mendefinisikan "Kinerja adalah gambaran mengenai tingkat pencapaian pelaksanaan suatu kegiatan / program / kebijaksanaan dalam mewujudkan sasaran, tujuan, visi dan misi organisasi yang tertuang dalam perumusan skema strategis (strategic planning) suatu organisasi”.

Kemudian Lembaga Administrasi Negara Republik Indonesia (1999) yang dikutip dalam Mukarom dan Laksana (2017:53) merumuskan "Kinerja sebagai gambaran mengenai tingkat pencapaian pelaksanaan suatu kegiatan, program, kebijaksanaan dalam mewujudkan sasaran, tujuan, misi dan visi organisisasi”.

\section{Indikator Kinerja Pegawai}

Menurut Gomes (2003:134) dalam Zuraini,dkk (2014:9) ada beberapa indikator-indikator kinerja pegawai, sebagai berikut : 
a. Quantity of work (Kualitas Kerja)

b. Quality of work (Kuantitas Kerja)

c. Job Knowledge (Pengetahuan Pekerjaan)

d. Creativeness (Kreatifitas)

e. Cooperation (Kerjasama)

f. Dependability (Kesadaran)

g. Initiative (Inisiatif)

h. Personal Qualities (Kualitas Pribadi)

\section{Hubungan Lingkungan Kerja terhadap Kinerja Pegawai}

Lingkungan kerja mempunyai hubungan yang sangat erat terhadap kinerja pegawai. Menurut Siagian (2002) dalam Zuriani, dkk (2014:4) bahwa "Kinerja pegawai dipengaruhi oleh beberapa faktor yaitu; gaji, lingkungan kerja, budaya organisasi, kepemimpinan, motivasi kerja, disiplin kerja, kepuasan kerja, komunikasi dan faktor-faktor yang mempengaruhi kinerja pegawai lainnya".

Dengan demikian lingkungan kerja merupakan suatu alat ukur yang akan berpengaruh terhadap kinerja pegawai. Di dalam sebuah kantor atau organisasi harus mampu menyediakan suasana lingkungan kerja yang nyaman, aman, dan kondusif. Dengan demikian, akan mampu mempengaruhi pegawai agar dapat bekerja dengan baik dan produktif.

\section{Hipotesis}

Menurut Pasolong (2013:84) bahwa "Hipotesis adalah suatu kesimpulan sementara, tetapi kesimpulan itu belum final, masih harus dibuktikan kebenarannya". Berdasarkan pengertian di atas maka peneliti membuat hipotesis sebagai berikut “Terdapat Pengaruh Positif dan Signifikan Antara Lingkungan Kerja Terhadap Kinerja Pegawai Di Dinas Perpustakaan dan Arsip Kabupaten Tangerang”.

\section{METODOLOGI PENELITIAN}

\section{Metode Penelitian}

Metode penelitian yang di gunakan pada penelitian ini adalah metode penelitian Kuantitatif - Asosiatif, dimana menurut Sugiyono (2018:7) bahwa "Metode penelitian kuantitatif adalah metode yang berlandaskan pada filsafat positivisme". Yang digunakan untuk meneliti pada populasi atau sampel tertentu, pengumpulan data menggunakan instrumen penelitian, analisis data bersifat statistik, dengan tujuan menguji hipotesis yang telah ditetapkan.

Kemudian menurut Sugiyono (2014:11) mengatakan "Penelitian Asosiatif merupakan penelitian yang bertujuan untuk mengetahui hubungan dua variabel atau lebih".

\section{Populasi dan Sampel}

\section{Populasi}

Menurut Sugiyono (2018:80) bahwa "Populasi adalah wilayah generalisasi yang terdiri atas obyek atau subyek yang mempunyai kualitas dan karakteristik tertentu yang ditetapkan oleh peneliti untuk dipelajari dan kemudian ditarik kesimpulannya".

Adapun obyek populasi dalam penelitian ini adalah pegawai Dinas Perpustakaan dan Arsip Kabupaten Tangerang dengan jumlah pegawai berdasarkan Golongan adalah 48 .

\section{Tabel 1}

Keadaan Pegawai Berdasarkan Golongan Di Dinas Perpustakaan Dan Arsip Kabupaten Tangerang

\begin{tabular}{|c|c|c|}
\hline No & Golongan & Jumlah \\
\hline 1 & IV & 9 \\
\hline 2 & III & 26 \\
\hline 3 & II & 13 \\
\hline \multicolumn{2}{|c|}{ Jumlah } & $\mathbf{4 8}$ \\
\hline \multicolumn{2}{|c|}{ Kumber $:$ Dinas Perpustakaan dan Arsip } \\
Kabangerang 2019
\end{tabular}

2. Sampel

Menurut Nawawi (1995:141) dalam Pasolong (2013:100) bahwa yang dimaksud "Sampel adalah sebagai bagian dari populasi yang menjadi sumber data yang sebenarnya dalam suatu penelitian". Ditinjau dari 
banyaknya anggota populasi di Dinas Perpustakaan dan Arsip Kabupaten Tangerang, maka peneliti menggunakan teknik pengambilan sampel, yaitu dengan teknik sampel jenuh (sensus).

Menurut Sugiyono (2018:85) bahwa "Sampel jenuh adalah teknik penentuan sampel bila semua anggota populasi digunakan sebagai sampel”. Dengan demikian dari populasi sebanyak 48 pegawai, maka peneliti mengambil seluruh populasi yang ada untuk dijadikan sampel di Dinas Perpustakaan dan Arsip Kabupaten Tangerang.

\section{Teknik Pengumpulan data}

Adapun teknik pengumpulan data pada penelitian ini menggunakan studi kepustakaan yaitu pengamatan obyek kajian teori yang relevan dan bahan ilmiah dari buku-buku literatur yang ada diperpustakaan. Kemudian studi lapangan yang merupakan upaya memperoleh data berkaitan dengan masalah yang dikaji dengan cara mengadakan penelitian langsung di lapangan meliputi : observasi, wawancara dan kuesioner (angket).

\section{Teknis Analisis Data}

Menurut Sugiyono (2018:147) bahwa "Analisis data merupakan kegiatan setelah data dari seluruh responden atau sumber data lain terkumpul". Kemudian menurut Siregar (2013:86) dalam Maydinur (2018:68) bahwa "Pada penelitian kuantitatif kegiatan analisis datanya meliputi pengolahan data dan penyajian data, melakukan perhitungan untuk mendeskripsikan data dan melakukan pengujian hipotesis dengan menggunakan uji statistik". Adapun teknik analisis data yang di gunakan dalam penelitian ini meliputi:

\section{Uji Validitas, Reliabilitas dan Normalitas}

Adapun dalam penelitian ini uji validitas digunakan untuk menunjukkan suatu tingkat-tingkat kevalidan atas kesahihan suatu instrumen. Kemudian uji reliabilitas digunakan untuk mengukur berkali-kali sehingga menghasilkan data yang sama (konsisten). Sedangkan uji normalitas digunakan untuk melihat apakah data yang akan dianalisis itu berdistribusi normal atau tidak.

\section{Uji Koefisien Korelasi}

Analisis korelasi digunakan untuk mengetahui kekuatan atau bentuk arah hubungan diantara dua variabel atau lebih, dan besarnya pengaruh yang disebabkan oleh variabel dependen atau bebas terhadap variabel terikat.

\section{Uji Koef Determinasi}

Selanjutnya untuk mengetahui besarnya pengaruh lingkungan kerja terhadap kinerja pegawai dihitung dengan menggunakan Koefisien determinasi atau yang sering disebut KD.

\section{Uji Regresi Linear Sederhana}

Analisis regresi dapat digunakan untuk memutuskan apakah naik dan menurunnya nilai dalam variabel dependen melalui menaikkan atau menurunkan nilai variabel independen.

\section{Uji Hipotesis}

Pengujian hipotesis dapat didasarkan dengan menggunakan dua hal, yaitu tingkat signifikan dan probabilitas $(\alpha)$ dan tingkat kepercayaan atau confidence interval.

\section{HASIL PENELITIAN DAN PEMBAHASAN \\ Hasil Uji Validitas}

Dalam uji vaiditas jika $r$ hitung $>r$ tabel $(0,285)$ maka kuesioner tersebut dinyatakan valid. Berdasarkan hasil rekapitulasi jawaban responden setelah dilakukan pengelolaan data dengan program SPSS Versi 21.0 dapat disimpulkan bahwa 11 pertanyaan yang berhubungan dengan lingkungan Kerja adalah valid untuk kesebelas pertanyaan. Dan 8 pertanyaan yang berhubungan dengan kinerja pegawai juga valid untuk kedelapan pertanyaanya. 


\section{Hasil Uji Reliabilitas}

Berdasarkan pengelolaan data dengan program SPSS Versi 21.0 dalam uji reliabilitas diketahui bahwa untuk variabel Lingkungan kerja memperoleh nilai Alpha Cronbach's $>\mathrm{r}$ tabel yakni $(0,875>0,285)$ maka kuesioner tersebut dinyatakan reliabel. Kemudian untuk variabel kinerja pegawai memperoleh nilai Alpha Cronbach's > r tabel yakni (0,875 > 0,285) maka kuesioner tersebut dinyatakan reliabel.

\section{Hasil Uji Normalitas}

Tabel 2

\section{Hasil Uji Normalitas Data Variabel} Lingkungan Kerja (X)

\begin{tabular}{|c|c|c|}
\hline \multicolumn{3}{|c|}{ Statistics } \\
\hline \multicolumn{3}{|c|}{ LINGKUNGAN_KERJA } \\
\hline \multirow[t]{2}{*}{$\mathrm{N}$} & Valid & 48 \\
\hline & Missing & 0 \\
\hline \multicolumn{2}{|c|}{ Mean } & 43,6250 \\
\hline \multicolumn{2}{|c|}{ Std. Error of Mean } & ,83189 \\
\hline \multicolumn{2}{|c|}{ Median } & 45,0000 \\
\hline \multicolumn{2}{|c|}{ Mode } & 45,00 \\
\hline \multicolumn{2}{|c|}{ Std. Deviation } & 5,76351 \\
\hline \multicolumn{2}{|c|}{ Variance } & 33,218 \\
\hline \multicolumn{2}{|c|}{ Skewness } &,- 532 \\
\hline \multicolumn{2}{|c|}{ Std. Error of } & ,343 \\
\hline \multicolumn{2}{|c|}{ Kurtosis } &,- 478 \\
\hline \multicolumn{2}{|c|}{ Std. Error of Kurtosis } &, 674 \\
\hline \multicolumn{2}{|c|}{ Range } & 23,00 \\
\hline \multicolumn{2}{|c|}{ Minimum } & 31,00 \\
\hline \multicolumn{2}{|c|}{ Maximum } & 54,00 \\
\hline \multicolumn{2}{|c|}{ Sum } & 2094,00 \\
\hline
\end{tabular}

Sumber : Hasil Perhitungan SPSS Versi

\section{0,Penelitian Tahun 2019}

Untuk menguji normalitas data dapat dihitung berdasarkan hasil dari Skewness dibagi dengan Std. Error of Skewness diperoleh dari hasil $-0,532: 0,343=-1,551$ dan nilai Kurtosis dibagi dengan Std.Error of Kurtosis diperoleh dari hasil $-0,478: 0,674=$ $-0,7091$ oleh karena itu kedua hasil tidak melebihi angka 2 dan -2 maka dapat didistribusikan data untuk fungsi lingkungan kerja adalah Normal.
Tabel 3

Hasil Uji Normalitas Data Variabel Kinerja Pegawai (Y)

\begin{tabular}{|c|c|c|}
\hline \multicolumn{3}{|c|}{ Statistics } \\
\hline \multicolumn{2}{|c|}{ KINERJA_PEGAWAI } & \\
\hline \multirow[t]{2}{*}{$\mathrm{N}$} & Valid & 48 \\
\hline & Missing & 0 \\
\hline \multicolumn{2}{|c|}{ Mean } & 29,9792 \\
\hline \multicolumn{2}{|c|}{ Std. Error of Mean } & ,61849 \\
\hline \multicolumn{2}{|c|}{ Median } & 30,5000 \\
\hline \multicolumn{2}{|c|}{ Mode } & 26,00 \\
\hline \multicolumn{2}{|c|}{ Std. Deviation } & 4,28500 \\
\hline \multicolumn{2}{|c|}{ Variance } & 18,361 \\
\hline \multicolumn{2}{|c|}{ Skewness } &,- 022 \\
\hline \multicolumn{2}{|c|}{ Std. Error of } & ,343 \\
\hline \multicolumn{2}{|c|}{ Kurtosis } &,- 944 \\
\hline \multicolumn{2}{|c|}{ Std. Error of Kurtosis } & ,674 \\
\hline \multicolumn{2}{|c|}{ Range } & 17,00 \\
\hline \multicolumn{2}{|c|}{ Minimum } & 23,00 \\
\hline \multicolumn{2}{|c|}{ Maximum } & 40,00 \\
\hline \multicolumn{2}{|c|}{ Sum } & 1439,00 \\
\hline
\end{tabular}

Sumber : Hasil Perhitungan SPSS Versi

\section{0,Penelitian Tahun 2019}

Untuk menguji normalitas data dapat dihitung berdasarkan hasil dari Skewness dibagi dengan Std. Error of Skewness diperoleh dari hasil $-0,022: 0,343=-0,0641$ dan nilai Kurtosis dibagi dengan Std.Error of Kurtosis diperoleh dari hasil $-0,944: 0,674=$ $-1,4005$ oleh karena itu kedua hasil tidak melebihi angka 2 dan -2 maka dapat didistribusikan data untuk fungsi kinerja pegawai adalah Normal.

\section{Hasil Uji Koefisien Korelasi}

Hasil Output SPSS Versi 21.0 diperoleh skor koefisien korelasi sebesar 0,725.

Tabel 4

\section{Hasil Koefisien Korelasi}

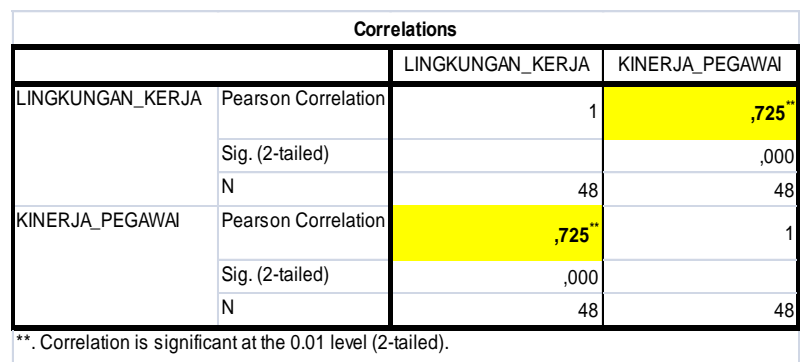

Sumber : Output SPSS Versi 21.0 
Maka berdasarkan hasil Output SPSS Versi 21.0 diatas, terdapat hubungan yang kuat antara lingkungan kerja terhadap kinerja pegawai pada Dinas Perpustakaan dan Arsip Kabupaten Tangerang, yang di tunjukan dengan $r=0,725$. Jika di interpretasikan menurut Sugiyono (2018:148) bahwa "Interval koefisien 0,600 - 0,799 termasuk pada kategori kuat ".

Tabel 5

Pedoman Untuk Memberikan Interpretasi Koefisien Korelasi

\begin{tabular}{|c|c|}
\hline Interval Koefisien & Tingkat Hubungan \\
\hline $0,00-0,199$ & Sangat Rendah \\
\hline $0,20-0,399$ & Rendah \\
\hline $0,40-0,599$ & Sedang \\
\hline $\mathbf{0 , 6 0}-\mathbf{0 , 7 9 9}$ & Kuat \\
\hline $0,80-1,000$ & Sangat Kuat \\
\hline
\end{tabular}

Sumber: Sugiyono(2018:184)

\section{Uji Koefisien Determinasi}

Dari Hasil Output SPSS Versi 21.0 diperoleh koefisien determinasi $\left(\mathrm{r}^{2}\right)=0725=$ 0,526 .

\section{Tabel 6}

\section{Hasil Perhitungan Koefisien Determinasi}

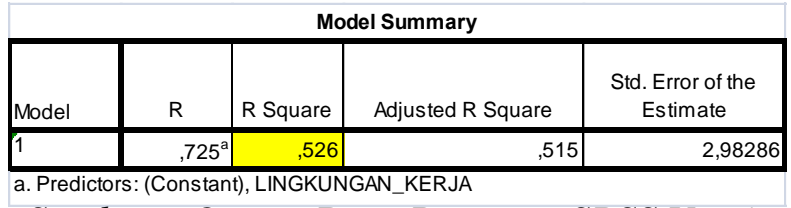

Sumber : Output Data Program SPSS Versi

21.0

Maka berdasarkan tabel 6, peneliti menyimpulkan bahwa lingkungan kerja memberikan pengaruh kepada kinerja pegawai sebesar $52,6 \%$ dan sisanya $47,4 \%$ di pengaruhi oleh faktor lain.

\section{Hasil Uji Regresi Linaer Sederhana}

Berdasarkan hasil Output SPSS Versi 21.0 pada tabel koefisien korelasi Lingkungan Kerja terhadap Kinerja Pegawai didapat nilai constant (a) dan coefficient (b) yang dapat dilihat oada tabel dibawah ini:

\section{Tabel 7}

Hasil Regresi Koefisien Korelasi

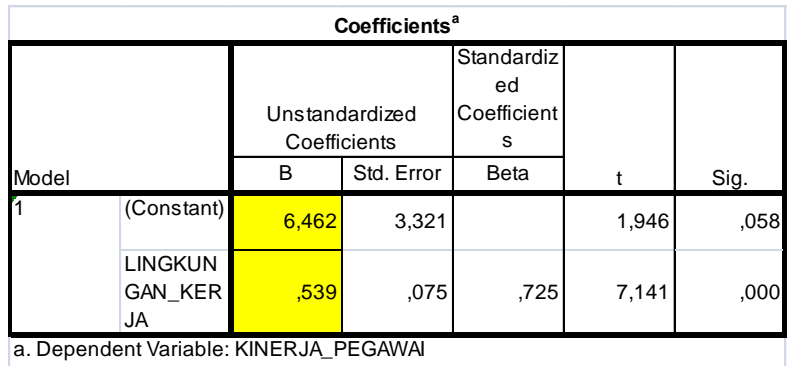

Sumber : Output Data Program SPSS Versi

21.0

Kemudian apabila dimasukan ke dalam rumus persamaan regresi, maka di peroleh:

$$
\begin{aligned}
& Y^{\prime}=\mathbf{a}+\mathbf{b X} \\
& Y^{\prime}=6,462+0,539 X
\end{aligned}
$$

Hubungan dua variabel atau lebih dikatakan memiliki hubungan positif karena nilai lingkungan kerja ditingkatkan maka kinerja pegawai juga meningkat. Sebagai contoh nilai lingkungan kerja ditentukan sebesar 1, maka kinerja pegawai dihitung sebagai berikut :

$$
\begin{aligned}
Y^{\prime} & =6,462+0,539(1) \\
& =7,001
\end{aligned}
$$

Jadi perkiraan nilai rata-rata kinerja pegawai akan meningkat sebesar 7,001 apabila lingkungan kerja dinaikan satu poin. Hal ini berarti membuktikan bahwa hubungan persamaan regresi variabel independen (X) searah terhadap naik turunnya variabel dependen (Y). Dengan demikian, hal ini membuktikan bahwa variabel (Y) searah atau berbanding lurus terhadap naiknya variabel (X). Hal ini berarti bahwa variabel lingkungan kerja memiliki hubungan yang positif dengan variabel kinerja pegawai.

\section{Uji Hipotesis}

Berdasarkan hasil Output SPSS Versi 21.0 pada tabel koefisien korelasi Lingkungan Kerja terhadap Kinerja Pegawai didapat nilai t hitung sebesar 7,141 sedangkan nilai $\mathrm{t}$ tabel dalam ketentuan uji signifikan $\mathrm{dk}$ : $48-2=46$ uji dua pihak dengan taraf signifikan 0,05 nilai $\mathrm{t}$ tabel yaitu sebesar 2,013 
Tabel 8

Hasil Regresi (T Hitung) Koefisien

Korelasi

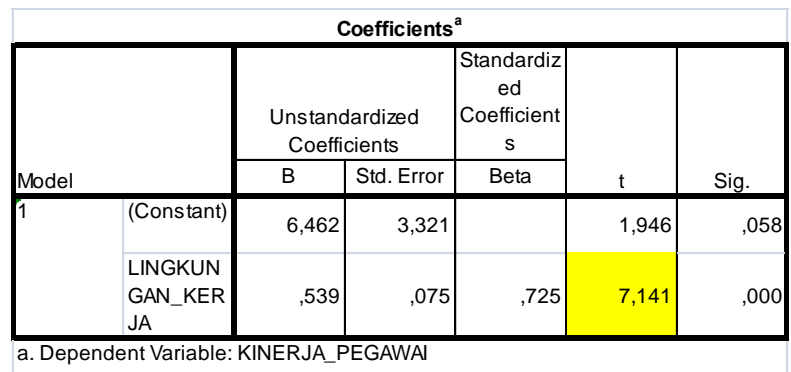

Sumber : Output Data Program SPSS Versi

21.0

Dengan demikian, dari tabel diatas sesuai dalam hitungan hipotesis statistik jika nilai $(7,141)>(2,013)$, Maka Ho ditolak dan Ha diterima, artinya bahwa: “Terdapat Pengaruh Positif dan Signifikan antara Lingkungan Kerja terhadap Kinerja Pegawai Di Dinas Perpustakaan dan Arsip Kabupaten Tangerang”.

\section{Analisis Hasil Penelitian}

\section{Variabel $X$ (Lingkungan Kerja)}

a. Penerangan/Cahaya

Berdasarkan hasil observasi dan penelitian kepada pegawai Dinas Perpustakaan dan Arsip Kabupaten Tangerang, yaitu untuk indikator Penerangan/Cahaya terdapat 28 responden dengan persentase $58,3 \%$ menjawab baik. Hal ini disebabkan karena penerangan/cahaya yang ada dalam ruang kerja pegawai dirasakan sudah baik, sesuai dan tidak menyilaukan pegawai Dinas Perpustakaan dan Arsip Kabupaten Tangerang dalam bekerja.

\section{b. Temperatur}

Berdasarkan hasil observasi dan penelitian kepada pegawai Dinas Perpustakaan dan Arsip Kabupaten Tangerang, yaitu untuk indikator Temperatur terdapat 21 responden dengan persentase $43,8 \%$ menjawab baik. Hal ini disebabkan karena temperatur udara pada Dinas
Perpustakaan dan Arsip Kabupaten Tangerang dirasakan pegawai sudah baik seperti pemakaian AC dengan pengaturan udara yang sesuai, tidak terlalu dingin dan tidak terlalu panas.

c. Kelembaban

Berdasarkan hasil observasi dan penelitian kepada pegawai Dinas Perpustakaan dan Arsip Kabupaten Tangerang, yaitu untuk indikator Kelembaban terdapat 16 responden dengan persentase $33,3 \%$ menjawab baik. Hal ini disebabkan karena tingkat kelembaban yang ada pada lingkungan kerja Dinas Perpustakaan dan Arsip Kabupaten Tangerang sudah baik seperti ruangan yang sangat dijaga kebersihan dan suhu udaranya sehingga pegawai merasakan kelembaban yang sesuai dalam ruang kerja.

\section{d. Sirkulasi Udara}

Berdasarkan hasil observasi dan penelitian kepada pegawai Dinas Perpustakaan dan Arsip Kabupaten Tangerang, yaitu untuk indikator Sirkulasi Udara terdapat 27 responden dengan persentase 56,3\% menjawab baik. Hal ini disebabkan karena sirkulasi udara pada Dinas Perpustakaan dan Arsip Kabupaten dirasakan pegawai sudah baik seperti adanya fentilasi udara yang sesuai sehingga memperlancar keluar masuknya udara dalam ruangan.

\section{e. Kebisingan}

Berdasarkan hasil observasi dan penelitian kepada pegawai Dinas Perpustakaan dan Arsip Kabupaten Tangerang, yaitu untuk indikator Kebisingan terdapat 18 responden dengan persentase $37,5 \%$ menjawab baik terhadap indikator Kebisingan. Hal ini disebabkan karena kondisi lingkungan kerja di Dinas Perpustakaan dan Arsip Kabupaten Tangerang sudah bebas dari 
kebisingan seperti pegawai yang sangat menjaga suasana agar tidak banyak suara gaduh atau kebisingan dalam bekerja, yang dapat menghambat kinerja pegawai.

\section{f. Getaran Mekanis}

Berdasarkan hasil observasi dan penelitian kepada pegawai Dinas Perpustakaan dan Arsip Kabupaten Tangerang, yaitu untuk indikator Getaran Mekanis terdapat 18 responden dengan persentase $37,5 \%$ menjawab baik terhadap indikator Getaran Mekanis. Hal ini disebabkan karena tingkat kebebasan lingkungan kerja Dinas Perpustakaan dan Arsip Kabupaten Tangerang dirasakan pegawai sudah baik, seperti tidak adanya getaran-getaran yang di timbulkan oleh peralatan mekanis di lingkungan kerja.

\section{g. Bau Tidak Sedap}

Berdasarkan hasil observasi dan penelitian kepada pegawai Dinas Perpustakaan dan Arsip Kabupaten Tangerang, yaitu untuk indikator bau tidak sedap terdapat 18 responden dengan persentase $37,5 \%$ menjawab cukup baik terhadap indikator bau tidak sedap. Hal ini disebabkan karena aroma (bau-bauan) yang ada di sekitar ruangan sudah cukup baik sehingga tidak mengakibatkan konsentrasi pegawai yang sedang bekerja terganggu, namun masih perlu di tingkatkan lagi.

\section{h. Tata Warna}

Berdasarkan hasil observasi dan penelitian kepada pegawai Dinas Perpustakaan dan Arsip Kabupaten Tangerang, yaitu untuk indikator tata warna terdapat 25 responden dengan persentase $52,1 \%$ menjawab baik. Hal ini disebabkan karena tata warna atau penggunaan warna pada ruangan di lingkungan kerja Dinas Perpustakaan dan Arsip Kabupaten
Tangerang di rasa sudah baik, seperti penggunaan warna abu-abu muda pada ruangan yang memberi efek pada psikologis pegawai seperti ketenangan sehingga cocok untuk meningkatkan keterampilan, konsentrasi dan kreativitas pegawai dalam bekerja.

\section{i. Dekorasi}

Berdasarkan hasil observasi dan penelitian kepada pegawai Dinas Perpustakaan dan Arsip Kabupaten Tangerang, yaitu untuk indikator dekorasi terdapat 19 responden dengan persentase 39,6\% menjawab baik. Hal ini disebabkan karena dekorasi pada ruangan di lingkungan kerja Dinas Perpustakaan dan Arsip Kabupaten Tangerang di rasakan baik.

\section{j. Musik}

Berdasarkan hasil observasi dan penelitian kepada pegawai Dinas Perpustakaan dan Arsip Kabupaten Tangerang, yaitu untuk indikator musik terdapat 17 responden dengan persentase $35,4 \%$ menjawab baik. Hal ini disebabkan karena musik yang di perdengarkan di Dinas Perpustakaan dan Arsip Kabupaten Tangerang seperti pada ruang perpustakaannya di rasakan sudah baik dan sesuai sehingga tidak mengganggu konsentrasi pegawai atau pengunjung.

\section{k. Keamanan}

Berdasarkan hasil observasi dan penelitian kepada pegawai Dinas Perpustakaan dan Arsip Kabupaten Tangerang, yaitu untuk indikator keamanan terdapat 22 responden dengan persentase $45,8 \%$ menjawab baik. Hal ini disebabkan karena kondisi keamanan pada lingkungan kerja Dinas Perpustakaan dan Arsip Kabupaten Tangerang di rasa sudah 
baik, dan tidak menggangu konsentrasi pegawai dalam bekerja.

\section{Variabel Y (Kinerja Pegawai)}

\section{a. Kuantitas Bekerja}

Berdasarkan hasil observasi dan penelitian pada Dinas Perpustakaan dan Arsip Kabupaten Tangerang, yaitu untuk indikator kuantitas bekerja terdapat 27 responden dengan persentase $56,3 \%$ menjawab baik. Hal ini disebabkan karena jumlah pekerjaan yang dikerjakan pegawai di Dinas Perpustakaan dan Arsip Kabupaten Tangerang sudah baik sehingga dapat berpengaruh dalam meningkatkan kinerja pegawai.

\section{b. Kualitas Bekerja}

Berdasarkan hasil observasi dan penelitian pada Dinas Perpustakaan dan Arsip Kabupaten Tangerang, yaitu untuk indikator kualitas bekerja terdapat 23 responden dengan persentase 47,9\% menjawab cukup baik. Hal ini disebabkan karena hasil pekerjaan yang dikerjakan pegawai di Dinas Perpustakaan dan Arsip Kabupaten Tangerang cukup baik dan bisa di tingkatkan lagi sehingga dapat berpengaruh dalam meningkatkan kinerja pegawai.

\section{c. Pengetahuan Pekerjaan}

Berdasarkan hasil observasi dan penelitian pada Dinas Perpustakaan dan Arsip Kabupaten Tangerang, yaitu untuk indikator pengetahuan pekerjaan terdapat 26 responden dengan persentase $54,2 \%$ menjawab baik. Hal ini disebabkan karena luasnya pengetahuan dan keterampilan pegawai di Dinas Perpustakaan dan Arsip Kabupaten Tangerang sehingga hasil pekerjaan yang didapat akan maksimal dan berpengaruh dalam meningkatkan kinerja pegawai.

\section{d. Kreativitas}

Berdasarkan hasil observasi dan penelitian pada Dinas Perpustakaan dan Arsip Kabupaten Tangerang, yaitu untuk indikator kreativitas terdapat 20 responden dengan persentase $41,7 \%$ menjawab baik. Hal ini disebabkan karena kreativitas pegawai di Dinas Perpustakaan dan Arsip Kabupaten Tangerang dalam bekerja sudah baik sehingga dapat berpengaruh dalam meningkatkan kinerja pegawai.

\section{e. Kerjasama}

Berdasarkan hasil observasi dan penelitian pada Dinas Perpustakaan dan Arsip Kabupaten Tangerang, yaitu untuk indikator kerjasama terdapat 21 responden dengan persentase $43,8 \%$ menjawab cukup baik. Hal ini disebabkan karena kerjasama pegawai di Dinas Perpustakaan dan Arsip Kabupaten Tangerang seperti kesediaan untuk bekerja sama dengan orang lain sudah cukup baik, namun bisa ditingkatkan lagi sehingga akan membuat pekerjaan lebih terasa ringan dan mudah serta dapat berpengaruh dalam meningkatkan kinerja pegawai.

\section{f. Kesadaran}

Berdasarkan hasil observasi dan penelitian pada Dinas Perpustakaan dan Arsip Kabupaten Tangerang, yaitu untuk indikator kesadaran terdapat 23 responden dengan persentase $47,9 \%$ menjawab baik. Hal ini disebabkan karena kesadaran pegawai akan perkerjaan di Dinas Perpustakaan dan Arsip Kabupaten Tangerang seperti ketepatan waktu dalam menyelesaikan pekerjaannya sudah baik sehingga dapat berpengaruh dalam meningkatkan kinerja pegawai. 


\section{g. Inisiatif}

Berdasarkan hasil observasi dan penelitian pada Dinas Perpustakaan dan Arsip Kabupaten Tangerang, yaitu untuk indikator inisiatif terdapat 23 responden dengan persentase $47,9 \%$ menjawab cukup baik. Hal ini disebabkan karena inisiatif pegawai di Dinas Perpustakaan dan Arsip Kabupaten Tangerang seperti kesadaran diri akan tugas dan semangat untuk melaksanakan tugas atau pekerjaannya sudah cukup baik sehingga dapat berpengaruh dalam meningkatkan kinerja pegawai.

\section{h. Kualitas Pribadi}

Berdasarkan hasil observasi dan penelitian pada Dinas Perpustakaan dan Arsip Kabupaten Tangerang, yaitu untuk indikator kuantitas pribadi terdapat 19 responden dengan persentase 39,6\% menjawab baik. Hal ini disebabkan karena kualitas diri pribadi seperti bentuk tingkah laku yang baik menyangkut kepribadian pegawai di Dinas Perpustakaan dan Arsip Kabupaten Tangerang seperti kepemimpinan, ramah-tamah, kejujuran pegawai sudah baik sehingga dapat berpengaruh dalam meningkatkan kinerja pegawai.

\section{Hambatan-Hambatan Yang Dihadapi Dalam Lingkungan Kerja Terhadap Kinerja Pegawai Di Dinas Perpustakaan Dan Arsip kabupaten Tangerang.}

Berdasarkan hasil penelitian menunjukan bahwa hambatan-hambatan yang dihadapi dalam Lingkungan Kerja dengan Kinerja Pegawai untuk mencapai hasil yang kurang maksimal di Dinas Perpustakaan dan Arsip Kabupaten Tangerang adalah sebagai berikut

1. Masih kurangnya dekorasi serta sarana dan prasarana yang belum lengkap, seperti pemakaian alat kantor yang masih dipakai bersama-sama sehingga mengakibatkan lambannya pencapaian tujuan pekerjaan.

2. Kurangnya rasa nyaman dalam bekerja karena masih sering terdapat aroma (baubauan) yang kurang sedap seperti dalam ruang depo arsip dan record centre sehingga mengganggu konsentrasi pegawai dalam bekerja.

3. Masih kurangnya kerjasama pegawai dalam bekerja dikarenakan kantor yang terpisah sehingga masih adanya hubungan yang kurang harmonis antar sesama pegawai.

4. Masih kurangnya kualitas kerja pegawai, dikarenakan kurangnya sumber daya manusia di kantor sehingga masih adanya hambatan dalam bekerja seperti pekerjaan yang masih lambat dalam pencapaiannya dan hasil yang dikeluarkan tidak sesuai dengan yang diminta atau masih ada kesalahan dalam output pekerjaan.

\section{KESIMPULAN DAN SARAN}

\section{Kesimpulan}

Setelah peneliti membahas tentang Pengaruh Lingkungan Kerja Terhadap Kinerja Pegawai Di Dinas Perpustakaan dan Arsip Kabupaten Tangerang, maka dapat ditarik beberapa kesimpulan sebagai berikut :

1. Hasil penelitian menunjukan bahwa lingkungan kerja memiliki nilai yaitu sebesar $81 \%$ dari kriteria yang ditetapkan.

2. Tingkat kinerja pegawai pada Dinas Perpustakaan dan Arsip Kabupaten Tangerang yaitu sebesar $75 \%$ dari kriteria yang di tetapkan.

3. Terdapat hubungan yang kuat antara lingkungan kerja terhadap kinerja pegawai pada Dinas Perpustakaan dan Arsip Kabupaten Tangerang, yang di tunjukan dengan $r=0,725$. Jika di interpretasikan menurut Sugiyono (2018:148) bahwa "Interval koefisien $0,600-0,799$ termasuk pada kategori kuat “. Dan koefisien determinasi $(\mathrm{r} 2)=0725=0,526$. Peneliti menyimpulkan bahwa lingkungan kerja memberikan pengaruh kepada 
kinerja pegawai sebesar $52,6 \%$ dan sisanya $47,4 \%$ di pengaruhi oleh faktor lain.

4. Terdapat pengaruh positif dan signifikan antara lingkungan kerja terhadap kinerja pegawai di Dinas Perpustakaan Dan Arsip Kabupaten Tangerang. Berdasarkan diperolehnya nilai t hitung sebesar 7,141 da nilai t tabel dalam yaitu sebesar 2,013. Dengan demikian, sesuai dalam hitungan hipotesis statistik jika nilai $(7,141)>$ (2,013), Maka Ho ditolak dan Ha diterima.

\section{Saran}

Berdasarkan kesimpulan diatas, peneliti memberikan saran sebagai masukan kepada Dinas Perpustakaan dan Arsip Kabupaten Tangerang, diharapkan agar dapat bermanfaat sesuai dengan keadaan lingkungan kerja untuk meningkatkan kinerja pegawai, yaitu sebagai berikut :

1. Kondisi lingkungan kerja di Dinas Perpustakaan dan Arsip Kabupaten Tangerang sudah baik, namun akan lebih baik lagi jika pada lingkungan kerjanya lebih melengkapi fasilitas-fasilitas atau sarana prasarana seperti rak-rak untuk buku-buku bacaan dan setelah itu mendekor ruang kerja pegawai dengan memperhatikan tata ruang dan tata letak nya sehingga arus kerja menjadi baik. Kemudian memfasilitasi pengharum ruangan pada ruang kerja agar pegawai lebih nyaman dalam bekerja.

2. Kondisi kinerja pegawai sudah baik maka perlu dipertahankan dengan pengawasan/pembinaan dari kepala dinas serta pemberian penghargaan bagi pegawai yang berkinerja baik diatas ratarata. Namun yang harus lebih ditingkatkan adalah pada kualitas kerja pegawai dengan lebih mengecek ulang hasil pekerjaan sehingga hasil pekerjaan menjadi lebih baik dan optimal serta lebih meningkatkan kerjasama pegawai dalam bekerja dengan menjalin komunikasi yang lebih baik antar sesama pegawai.

\section{DAFTAR PUSTAKA}

Fahmi, Irham. 2015. MANAJEMEN KINERJA

Teori dan Aplikasi. Bandung : CV. ALFABETA.

Maydinur, Elya. 2018. Pengaruh Good Governance Terhadap Kinerja Pegawai Pada Dinas Tenaga Kerja Kabupaten Tangerang. SKRIPSI. Universitas Islam Syekh-Yusuf Tangerang.

Mukarom, Zaenal dan Laksana, Muhidin W.

2016. Membangun Kinerja

Pelayanan Publik. Bandung :

Pustaka Setia.

Nitisemito, Alex S. 1982. Manajemen

Personalia. Jakarta : Ghalia

Indonesia.

Pasolong, Harbani. 2013. Metode Penelitian

Administrasi Publik. Bandung :

ALFABETA.

Sedarmayanti. 2011. Tata Kerja dan

Produktivitas Kerja. Bandung : CV. Mandar Maju.

Sugiyono. 2014. Metode Penelitian

Administrasi. Bandung

ALFABETA

Sugiyono. 2018. Metode Penelitian Kuantitatif, Kualitatif, dan $R \& D$. Bandung : ALFABETA

Weol, David H. 2015. "Pengaruh Lingkungan Kerja, Pelatihan Dan Penempatan Terhadap Kinerja Pegawai Di Dinas Pendidikan Nasional Provinsi Sulawesi Utara”. Jurnal Berkala Ilmiah Efisiensi. Volume 15 No. 05.

Zuriani, Silfina dkk. 2014. Pengaruh Lingkungan Kerja Terhadap Kinerja Pegawai (Studi di Dinas Pendidikan dan Kebudayaan Kota Tanjungpinang). Naskah Publikasi. Universitas Maritim Raja Ali Haji Tanjungpinang. 